DOI: 10.21625/resourceedings.v2i3.620

\title{
The role of geometry on stability of large domes: Roman Pantheon as cultural emblem and constructive reference
}

\author{
Claudia Cennamo $^{1}$, Concetta Cusano ${ }^{1}$ \\ ${ }^{1}$ Department of Architecture and Industrial Design, University of Campania "Luigi Vanvitelli", Aversa, Italy \\ Email: claudia.cennamo@unicampania.it,Email: concetta.cusano@unicampania.it
}

\begin{abstract}
This paper focuses on large domes' building techniques and use of geometric rules in the design and construction of religious structures. A quick excursus on the cultural heritage in Italy and abroad highlights how domes have been used almost exclusively in sacred architecture, rather than in civic buildings, for most of history. Born of the need to cover large spaces without facing with the encumbrance of vertical elements, the domed cover, ideal for places of worship crowded by hundreds of faithful, has assumed, over the centuries, a symbolic meaning to every religion. In fact, identifying the shape of a large dome in the urban landscape immediately means to recognize the sacredness of that place. The ancient Romans who believed in the gods, Christians, Hindus and Muslims, all used this very peculiar architectural element in churches or mosques to express a kind of spiritual symbolism and, as mentioned, the fact that the shape of the dome arises from a functional reason, it has over time got pushed aside. Furthermore, the circle is a geometric form that possesses a great symbolic force, generated by the idea that, having no beginning and no end, reflected perfection, the eternal, and also the heavens. In this perspective, drawing a circle both in the horizontal and vertical section, the ultimate paradigm for all monumental domes was the Roman Pantheon which, with its centrally placed "oculus" or "eye of heaven" proved to be a model for all other domes after it, retaining its position as the most ancient and well preserved dome in the world. Therefore, this article concentrates on the study of the Pantheon as an emblem and reference model for all monumental domes. By analyzing the "meaning" of its architectural design and its structural and geometric characteristics, the research dissects a comparison between similar large domes, similar to each other, such as that of St. Francesco di Paola in Naples and the Mosta Dome in Malta. The comprehension of these valuable architectural artifacts lies between the search for their original geometry and the identification of structural models through which their shape was defined, namely the geometric and proportional rules of the past.
\end{abstract}

(C) 2019 The Authors. Published by IEREK press. This is an open access article under the CC BY license (https://creativecommons.org/licenses/by/4.0/).

\section{Keywords}

Masonry; Large Domes; Shape and Structure

\section{Introduction}

The Romans began to build large vaults and domes about 2000 years ago, and the largest of all, the Pantheon, was built in Rome in 123 AD. (Cowan, 1977).

Since the Middle Ages, the Pantheon has been an important architectural model and influenced the shape of new buildings. During the Renaissance, this position obviously became more pronounced and it was the real reason for so many of the sketches and studies on the monument. In the later centuries, the rotunda was the main architectural 
feature and an inexhaustible source of inspiration. In many Italian cities, churches and monuments are a proof of the influence of the Pantheon (De Fine Licht, 1968).

Some examples can be found in Venice in the Church of S. Simeone Piccolo (1718-38) by G. Scalfarotto (Figure 1); in Turin with the Church of Gran Madre di Dio (1818-31) on the Ponte Vittorio Emanuele, built by Se Bonsignore (Figure 2) and in Naples with the Basilica of S. Francesco di Paola in Piazza del Plebiscito.

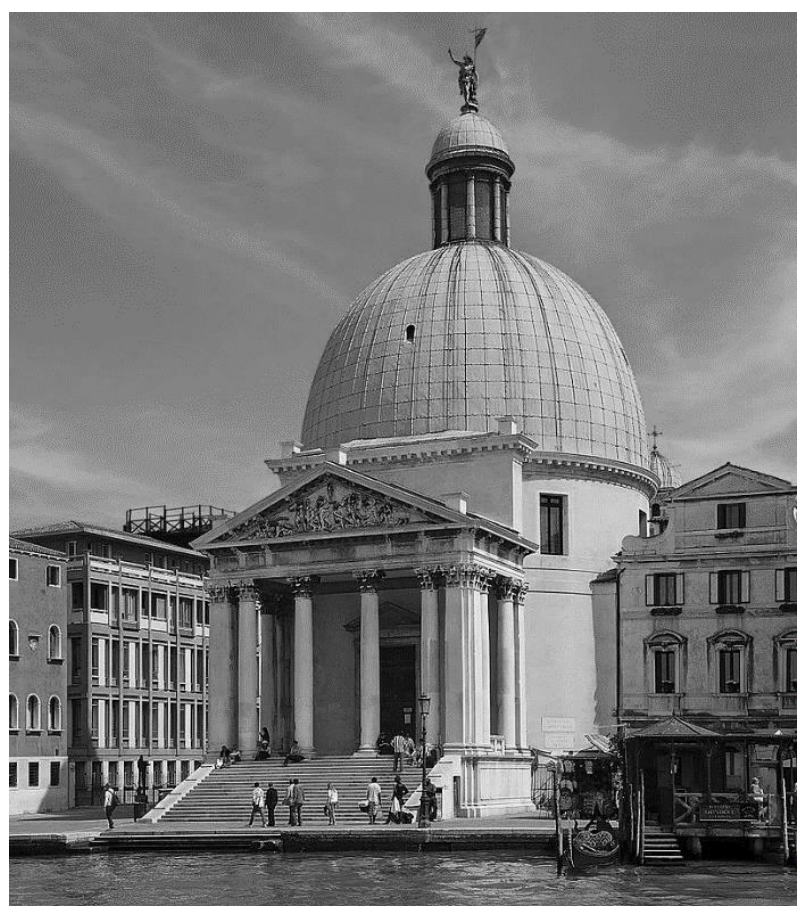

Figure 1. Venice, Church of S. Simeone Piccolo.

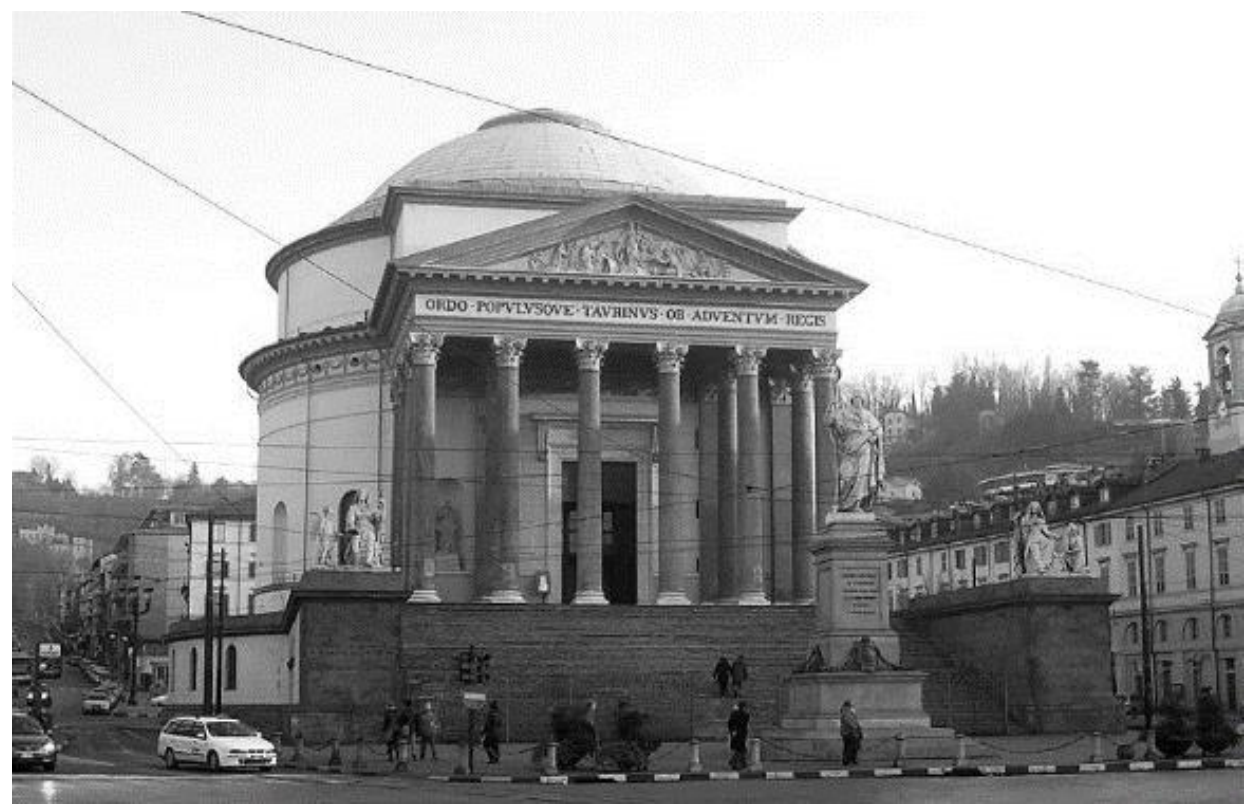

Figure 2. Turin with the Church of Gran Madre di Dio.

The Danish architects C.F. Harsdorff, C.F. Hansen and C.F.F. Stalnley are among the foreign artists who have studied and designed the Pantheon. Harsdorff lived in Rome from 1762 to 1764 and his interest in the Pantheon came to light unequivocally in his suggestion for the Church of Frederiks in Copenhagen (Figure 3). The Rotonda di Mosta in Malta (Figure 4) is also greatly influenced by the Pantheon, in line with the attitude of rediscovering the ancient world that characterizes the nineteenth century. 


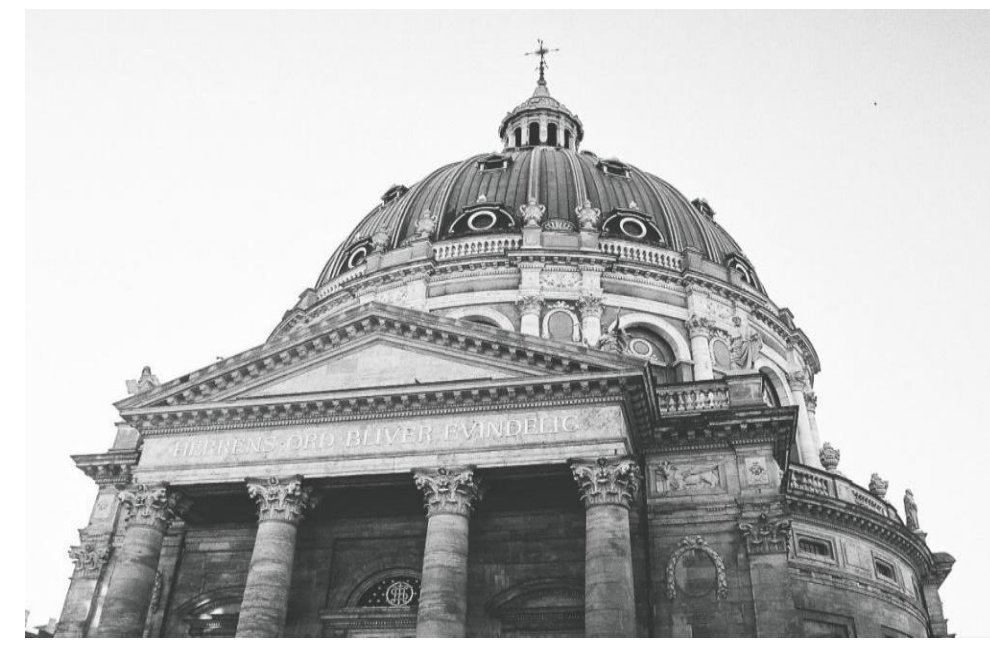

Figure 3. Frederik's Church, Copenhagen. External view of the dome (Bossut, 1802).

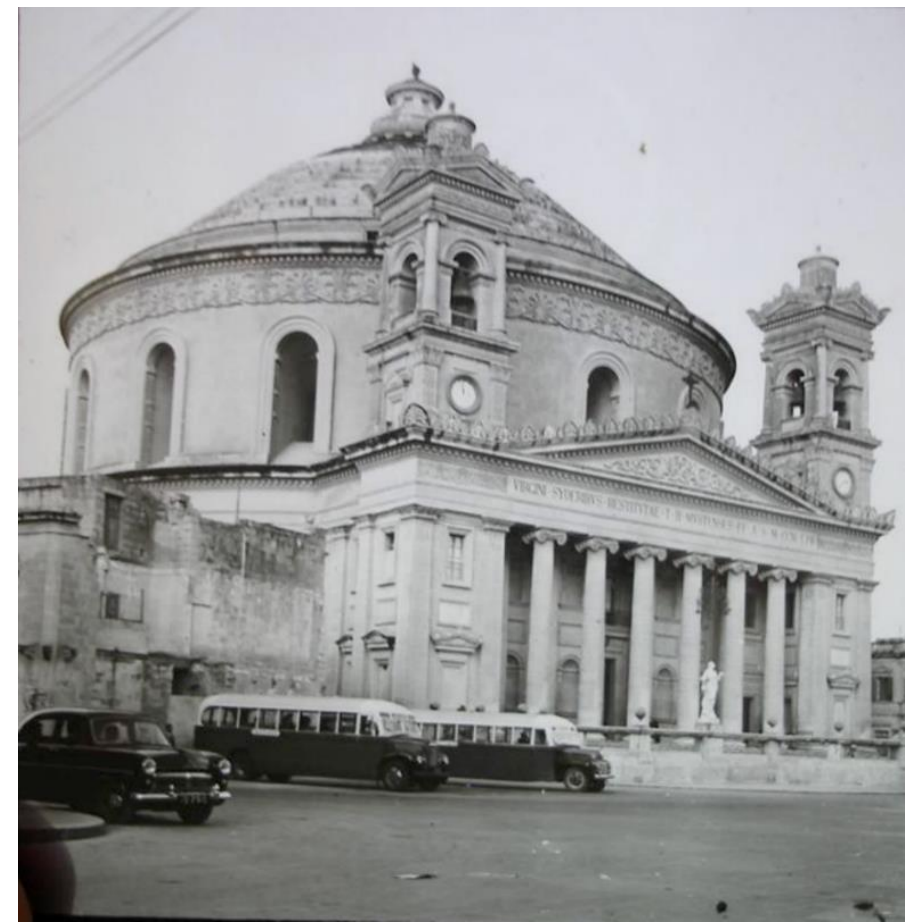

Figure 4. Rotunda of Mosta, Malta (Mascheroni, 1785).

\section{The Pantheon dome: shape and structure}

The Pantheon represents the creative synthesis of three very important architectural aspects, such as the emphasis on the interior space, the survival of classical forms and the use of concrete. It is a circular room, surmounted by a large hemispherical dome and preceded by a pronaos of Greek origin. The portico, about 33,10 meters wide and 15,50 meters deep, is characterized by 16 Corinthian columns more than 12,50 meters high, with monolithic shaft in gray and pink granite, eight of which are on the front and the others are placed so as to create three naves. The main body has circular perimeter walls with a thickness of 6,5 meters, above which the hemispherical dome stands with an internal diameter of 43,20 meters, exactly equal to the net height of the temple.

The circular building was built with bricks and concrete (opus caementicium), and the arrangement of these materials is not accidental: the lighter materials were placed at the top to relieve the great weight of the dome. The series of arches that make up the cylindrical body (Figure 5), meanwhile, was mostly built using bricks. The arches were mainly used to support the weight of the structure and to direct the loads towards the walls and pillars of the Pantheon up to the foundations. 


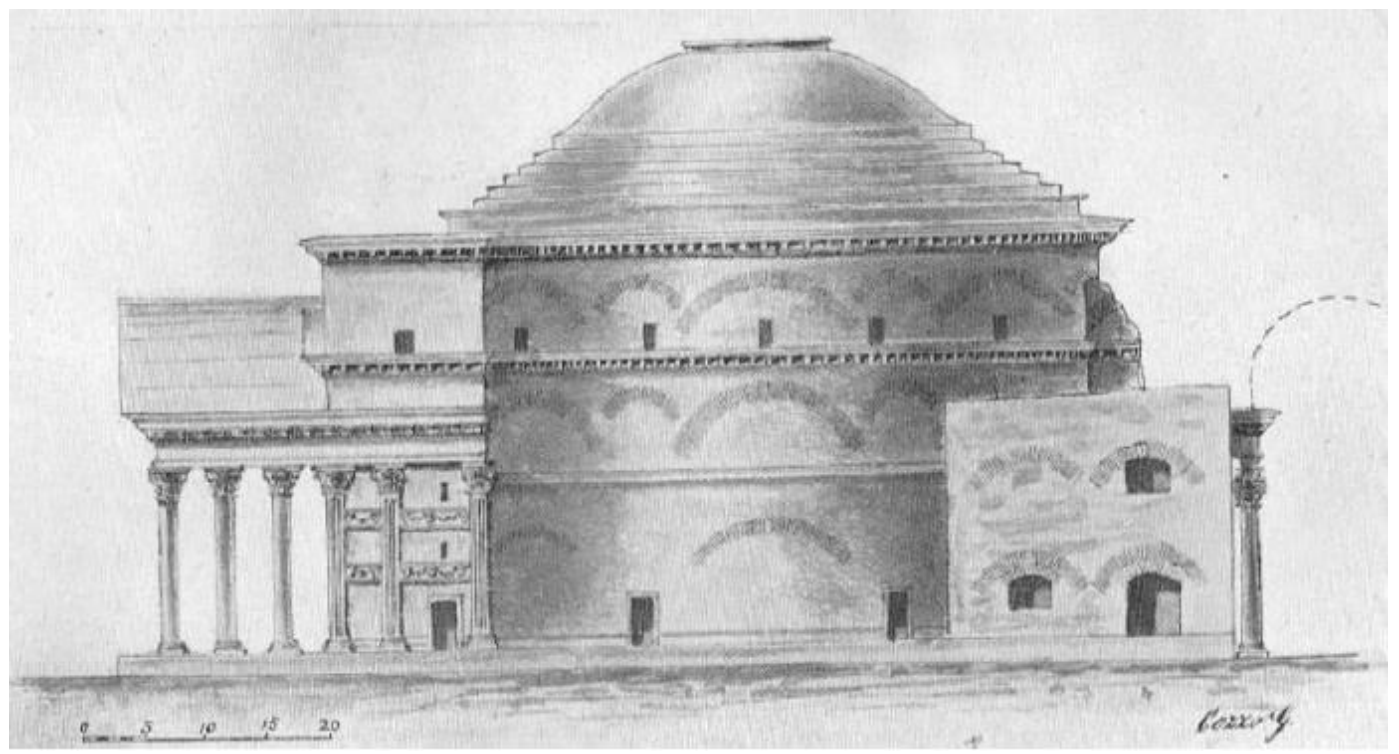

Figure 5 Outside of the Pantheon with the three orders of arches (table CXVI, Cozzo)

The dome is entirely made of Roman concrete whose outer surface, originally covered in bronze, is currently covered in lead; its interior is lightened by five rings of 28 lacunars that gradually reduce in size towards the center. In the upper part of the dome there is an opening towards the sky (oculus) which has a diameter of 8,80 meters and has a decorative frieze in bronze foil.

\section{A comparison between similar domes}

\subsection{The influence of the Pantheon on the Basilica of San Francesco di Paola in Naples}

The hemispherical dome is the typical coverage used in central-plan spaces, where the character of spatial continuity instead of the perception of verticality predominates. In Naples, the hemispherical dome roofing system has not had much application, not even in the case of religious buildings except for the case of the Basilica of San Francesco di Paola. This is probably due to the fact that the hemispherical dome typology was created as an element designed to cover temples with a single hall, which corresponds to the typology of pagan architecture, far from the cross typology of the Christian religion (Sasso, 1856). It was King Ferdinand IV himself who proposed the Pantheon as a reference model for the Basilica of San Francesco di Paola, both in terms of geometry and proportions and for its strictly compositional and formal configuration (Jandoli, 1999). In this paragraph, attention is focused on the comparison between the two similar domes, from a formal and more properly structural point of view. Firstly, from the comparison between the two domes, different geometric relations have been identified (Figure 6\&7).

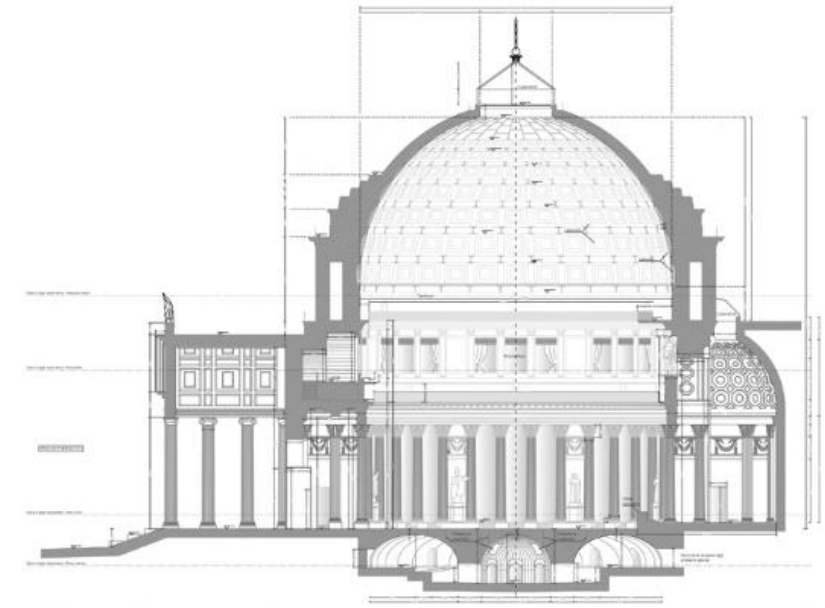

Figure 6. Section of the Basilica of San Francesco di Paola (Tecno IN Geosolutions). 


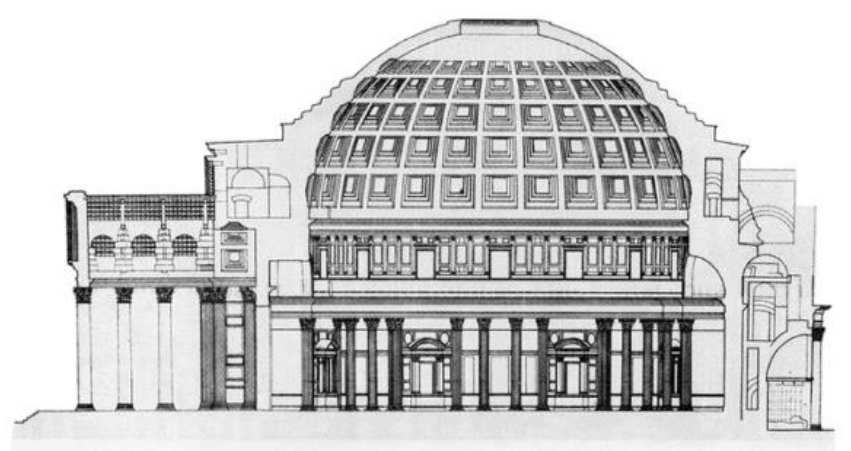

Figure 7. Section of the Pantheon (De Fine Licht 1968).

The Basilica of San Francesco di Paola is 53 meters high and has a diameter of about 36 meters, while the Pantheon is 43,20 meters high with an exact corresponding diameter. This implies a different spatial perception, in which Bianchi's dome covers a more exploited space. The lighting is obtained, as in the Pantheon, by means of a central oculus of about 9 meters in diameter that ends with a lantern of reinforced glass. The dome of the Pantheon is modelled on a sphere within a cylinder; it should be noted that the internal geometry of the dome creates a perfect sphere (Cusano, 2019). The height of the rotunda to the top of the dome corresponds to its diameter, which is the substantial difference between the two analyzed domes (Figure 8\&9).

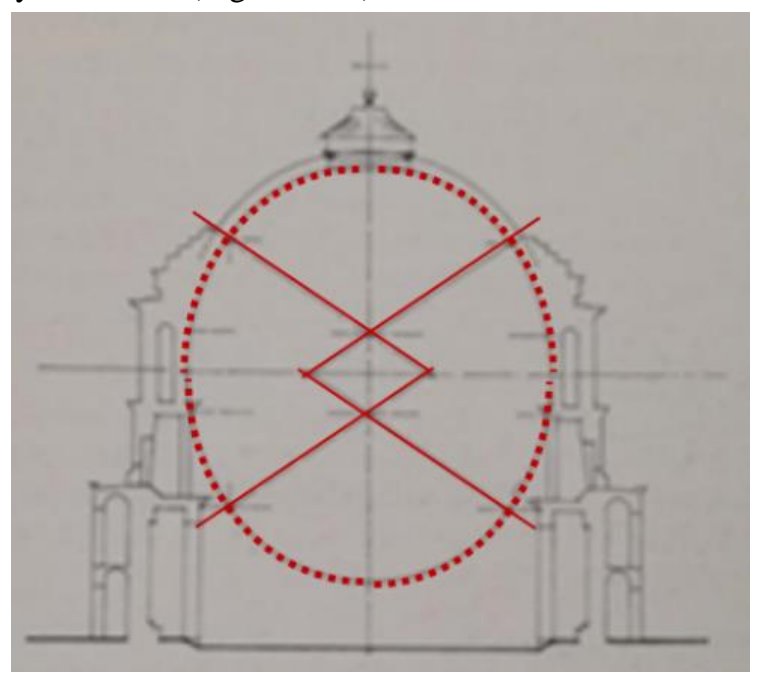

Figure 8. Dome of San Francesco di Paola.

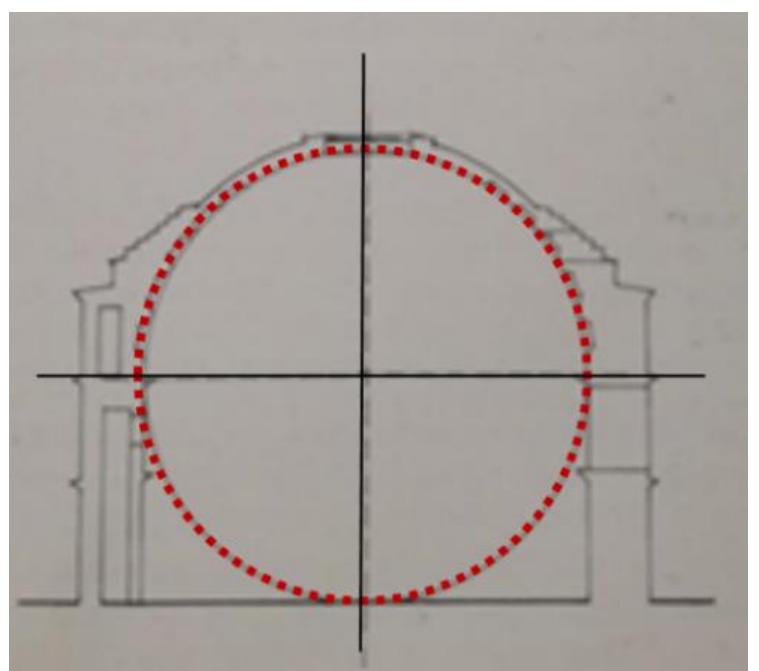

Figure 9. Dome of the Pantheon (Jandoli 1999, modified by the author adding the schemes in red). 
Outside, the dome of San Francesco di Paola is covered with lead and articulated with the vertical structure of the drum by means of four circular steps. The dome ends with a lantern, which is accessible from the outside through the four staircases at the back of the dome. On the outer surface of the Pantheon's dome, there are 7 rings stacked one above the other and having an uneven diameter; they are placed one above the other with their decreasing diameters as they are stacked. The height of these rings varies and it amounts to around 0,80 meters. In addition, there is an external staircase which, through these rings, leads to the oculus (Cennamo, Cusano, Angelillo, 2018a). The elimination of the circular steps, would mean that the thrust of the dome is no longer contained within its section, causing a possible collapse of the structure (Cennamo, Cusano, Fortunato, Angelillo, 2018b). Therefore, each element of the dome, is necessary to support each other and to rationally distribute the forces. The Romans' intuition to reduce the thickness of the dome and make it stable even by creating a central opening (oculus), has made the Pantheon an incredible structure of reference for future generations.

\subsection{The rotunda of Mosta in Malta}

The engineering interest in the building led James Fergusson ${ }^{1}$ to include it in his classic publication History of the Modern Styles of Architecture in 1862 (Figure 10, 11 \& 12). Built between 1833 and 1871 on the basis of drawings by Giorgio Grognet de Vassé, it is clearly inspired by the architectural engineering of the Pantheon in Rome (Figure 13). Recently, some authors have also argued that its configuration may have been influenced by the contemporary dome of the church of San Francesco di Paola in Naples (Stamp, 2012).

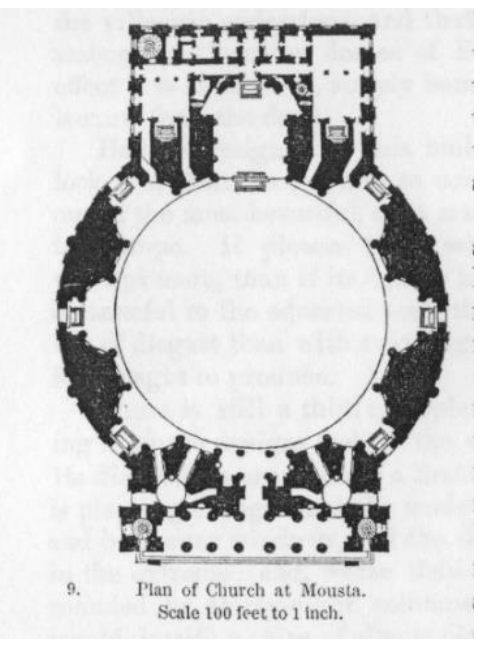

Figure 10. Church of Mosta. Plan

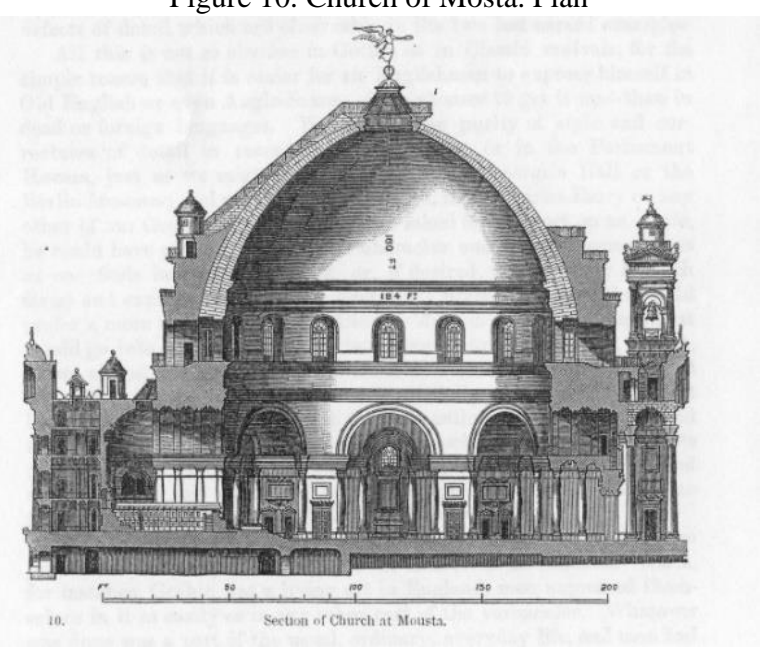

Figure 11. Section. Drawings by Fergusson (1862).

\footnotetext{
${ }^{1}$ James Fergusson (1808-1886), a well-known Scottish architectural historian from the late 19th century.
} 
The dome of this church covers an area of 37,20 meters in diameter and it is completely made of limestone (White, 2018). Recalling Vitruvius' definition of architecture as "utilitas, firmitas, venustas" (Wotton, 1624), Grognet himself used the Pantheon in a comparative manner to prove that his design was also stable, functional and aesthetically pleasing.

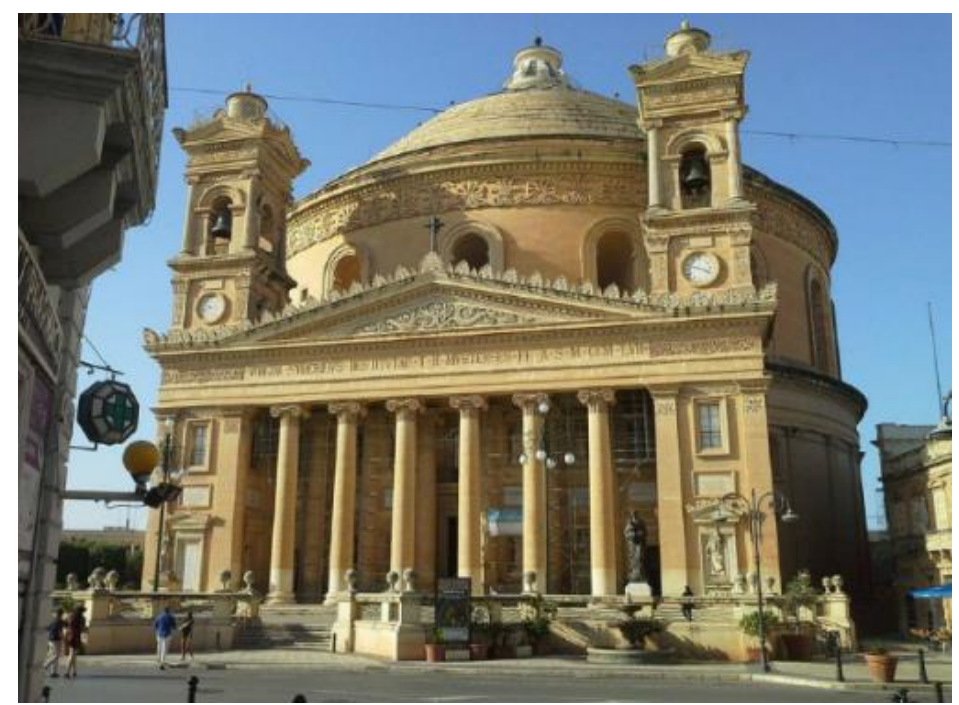

Figure 12. Church of Mosta

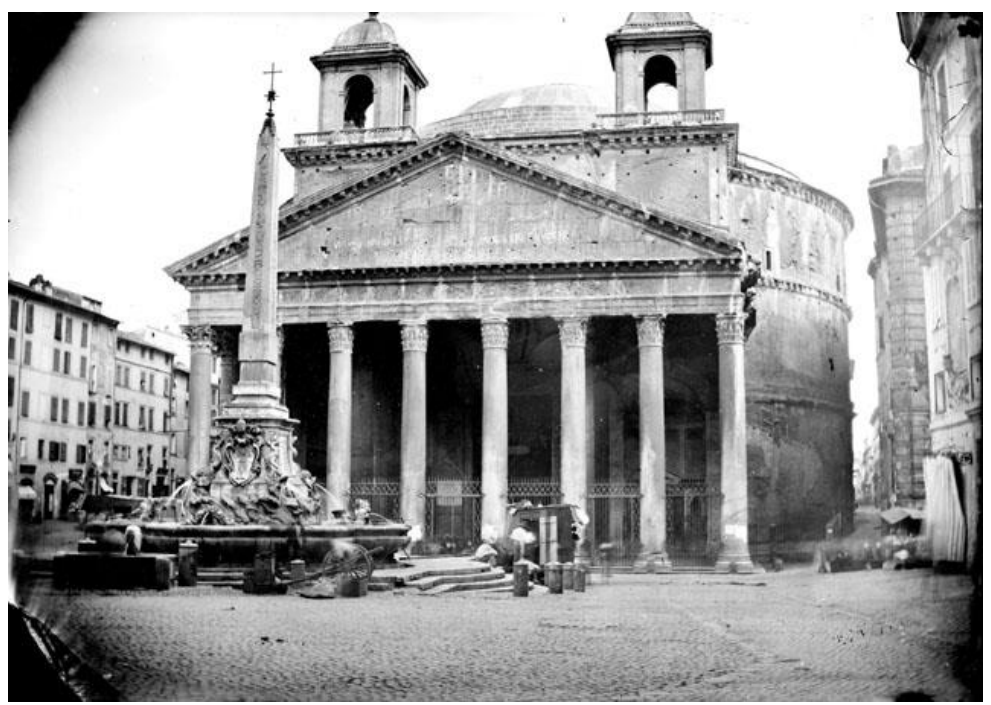

Figure 13. Photograph of the late nineteenth century Pantheon in Rome (White, 2018).

In terms of firmitas, during the construction, the Church he designed could be erected without disturbing the religious services; from the point of view of utilitas, it was configured with a space large enough to satisfy the growing population of the city. The component of venustas was inspired by "a great beauty and uniqueness, but above all a desired variety in Malta, where almost all the Churches are subservient to each other" (Grongnet de Vasse, 1833a). The possibility of building the dome designed by Grognet was questioned by various structural engineers, whose worries concerned the structural stability of the proposed project (Grognet de Vassé, 1833a). The structural engineering properties of Malta's limestone were a legitimate issue at the time (White, 2018). However, in addition to explaining his choice for a circular shape as a design solution, Grognet, declared that, given the low quality of the stone of Malta, the masonry drum would be sufficient to support the dome. To demonstrate this, he once again referred to the Pantheon and the principles dictated by Francesco Milizia (1725-1798), the main exponent of the time on the history and theory of architecture. With reference to Principij di Architettura Civile (Militia, 1785), Grognet calculated the compressive stress that the drum was able to withstand, and claimed the existence of a safety factor on 
the static loads generated. This comparison was followed by an undated technical report by Grognet entitled Relazione sul mio Progetto per la nuova Chiesa da Fabricarsi di pianta in Casal Musta (Grognet de Vassé, 1833b), a document written before May 1833 and containing his calculations of structural engineering, developed in detail, to demonstrate the possible construction and stability of the designed dome.

\section{Conclusions}

From the discussion carried out in this article it is clear, without any doubt, how the Pantheon has been considered for centuries the archetype of buildings with central plan, of which it represents a design example of clear proportions. At the beginning of the 15 th century, the so-called renovatio, or rebirth of ancient values, led to an intensive study of Roman buildings and above all the Pantheon became a model of a common investigation for most of the authors who dealt with the importance of Roman antiquities. This appreciation of the monument is intensely expressed in the Renaissance period, through the drawings and comments of various authors. In the 16th century, the relationship between architects and ancient buildings began to change and they were accepted as purely theoretical models. Faced with the search for construction rules expressed in architectural treatises, in this period a tendency to break away to carry out new experiments is emerging. Neoclassicism proposes a new relationship with the classical world: even if a return to the ancient world is proposed, it is acknowledged that it is impossible to recover classical values in the present. Therefore, an almost scientific conception of Roman monuments and remains seen as an archaeological source is born, which requires a type of objective documentation. The interest in centralized buildings involves the study of domes with spherical geometry, roofing systems closely linked to these planimetric solutions. Table 1 shows a list of the largest masonry domes built and it can be seen that the 43 meters' span of the Pantheon in Rome continues to be the maximum coverage for an unreinforced masonry vault.

\section{References}

Bianco L. (2018). A geohistorical retrospective analysis of cultural heritage buildings: the case of Mosta Dome, Malta. Springer Science+Business Media B.V., part of Springer Nature.

Bossut C. (1802). Saggio generale di storia delle matematiche, Milano, Nobile e Tosi.

Cennamo C., Cusano C., Angelillo M. (2018). On the statics of large domes: a static and kinematic approach for San Francesco di Paola in Naples, in Proc. of the 10th International Masonry Conference, G. Milani, A. Taliercio and S. Garrity (eds.), Milan, Italy.

Cennamo C., Cusano C., Fortunato A., Angelillo M. (2018). A study on form and seismic vulnerability of the dome of San Francesco di Paola in Naples, Ingegneria Sismica, International Journal of Earthquake Engineering, 35(1):88-108

Cowan H. (1977). Domes - Ancient and Modern. Architectural Science Review, 20: pp. 38-43.

Cusano C. (2019). The dome of San Francesco di Paola. Geometry, construction and stability in the design of domes in the first half of the nineteenth century. Doctoral Thesis (XXXI cycle) in Architecture, Industrial Design and Cultural Heritage. University of Campania Luigi Vanvitelli. Tutor: Claudia Cennamo; co-tutor: Santiago Huerta Fernández.

De Fine Licht K. (1968) The Rotunda in Rome: A Study of Hadrian's Pantheon. Edición Gyldendal.

Fergusson J. (1862). History of the modern styles of architecture: Being a sequel to the handbook of architecture. London: John Murray.

Grognet de Vassé G. (1913). Correspondence dated 18 January 1833. In E. W. Salomone (Ed.), La Rotonda della Musta: Relazione architettonica del Grognet: documenti editi (pp. 9-12).

Grognet de Vassé G. (1913). Relazione sul mio Progetto per la nuova Chiesa da Fabricarsi di pianta in Casal Musta. In E. W. Salomone (Ed.), La Rotonda della Musta: Relazione architettonica del Grognet: documenti editi. pp. 15-21.

Jandoli A. (1999). L'utilizzo della cupola emisferica: la Chiesa di San Francesco di Paola in Napoli versus coelum. La città e le sue cupole edited by Adriana Baculo Giusti, Antonella di Luggo, Riccardo Florio. Napoli: Electa.

Mascheroni L. (1785). Nuove ricerche sull'equilibrio delle volte, Bergamo.

Mettam GR, Adams LB. (1999). How to prepare an electronic version of your article. In: Jones BS, Smith RZ, editors. Introduction to the electronic age. New York: E-Publishing Inc. pp. 281-304.

Sasso CN. (1856). Storia dei monumenti di Napoli e degli architetti che li edificarono. Napoli, 2, pp.123-134.

Stamp G. (2012). Domes. Apollo, 175(595), pp.74-75.

Strunk Jr W, White EB. (1979). The elements of style. 3rd ed. New York: Macmillan.

Van der Geer J, Hanraads JAJ, Lupton RA. (2000). The art of writing a scientific article. J Sci Commun. 163, pp.51-9.

Wotton, W. (1624). The elements of architecture. London: John Bill. 